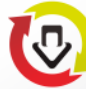

Check for

updates

\section{The Role of Venture Capital on Start-up Business Development in Indonesia}

\author{
Meita Clara Wijaya Rosa*, Eko Ganis Sukoharsono, Erwin Saraswati
}

ABSTRACT: This research aimed to determine the criteria used by venture capital before investing in start-up companies, and the role of venture capital as a supporter of the start-up companies in Indonesia. This research is qualitative descriptive with a case study research approach. It was conducted in the venture capital in the city of Jakarta, using interview to collect the data. The results of this research indicate that the criteria used by venture capital before carrying out the investment process are, seeing team members, the products to be offered, marketing and exit strategies. The role of venture capital is as a supporter of the start-up companies in Indonesia by helping their funding access, assisting them to grow, supporting networking activities and mentoring, and helping them to expand the market access for the start-up products.

KEYWORDS: venture capital; investment; start-up; companies

\section{Introduction}

The rapid development of information and communication technology today is revolutionary changing human life, from lifestyle to how to do business. The era of digitalisation changed a lot of business practices long ago and then replaced with the new ways that are faster and more efficient. Companies that do not want to change and adapt to the technological developments will be displaced in an increasingly competitive market. Companies that do not change and adapt to technology will be displaced in competitive markets. Changes as a result of digital technology advances cause shocks or disruptions that change lifestyles, personal relationships or business activities (Kasali, 2017).

Currently, a solution is needed to run business activities in an economical and efficient way, but changing business conditions have increased challenges and pressures. Thus, approaches and solutions are different from the common ways (Ehrenfield, 2008). Business changes are needed both fundamentally and technically, and the changes occur not only in the structure of costs but also in the culture to business models. Keuschnigg (2004) stated that venture capital has a role in generating new business models that are believed to make start-ups grow faster and have added value. In addition, the results of work and innovation produced are more than the old business models.

The role of venture capital can be seen as an important link to support business continuity. Before investing in start-ups, the analysts or internal parties of the venture capital will conduct analysis and selection of the startup companies. Ramdhan (2016) stated that the funding mechanism undertaken by venture capital is different from other financial industries and is considered to have a high risk, so special analysis is needed before deci- 
ding to invest in start-up companies.

Start-up companies are a kind of entrepreneurship and new business in the form of companies, organizations and partnerships that are engaged in technology (Kiwe, 2018). They are generally designed to look for repeat and measurable businesses, and can be developed into the larger (scalable) ones. The effort taken to develop the start-up business is in the form of innovation at the various stages of its development. Innovation is generally done to find various answers and solutions that arise in the community, so that the products produced have benefits in everyday life.

Tecker, Teker and Teraman (2016) mentioned that in the United States from 1991 to 2014 many companies were funded by venture capital which contributed greatly to the growth of the US start-up companies. During the period of 1991-2014, there had been 11,686 companies funded by venture capital companies. In Indonesia, the development of venture capital companies that fund start-up companies has not been officially registered because the government has not made clear and specific regulations for the venture capital. Based on the data released by OJK (Financial Services Authority), it was recorded that the growth of the venture capital in 2015 reached 61 companies operating and carrying out their activities in Indonesia.

Bocken (2015) said that venture capital companies contributed a lot to the growth of the start-up companies in Europe and the USA. However, venture capital companies remain cautious in determining investment. In accordance to Buchner, Abdulkadir and Armin (2017), the investment decisions made by the managers in the venture capital companies are reflected in serious investment analysis, especially to assess the expertise in fund management by the start-up companies as potential investees.

Lee (2017) in his research on the peer-network identification and measurement of the venture capital role towards start-up companies found that many start-up companies have partnered with venture capital companies based on the provided capital assistance and the success of creating innovative products made by the start-ups.

Research related to collaborative issues of venture capital and start-up companies is still very rare, especially in the context of developing countries like Indonesia. Based on this reasoning, this research dug up the information related to the criteria used by the venture capital companies before investing in start-ups, as well as the role of the venture capital as the supporter of the start-up companies in Indonesia. This research was conducted based on that conducted by Bocken (2015) focusing on exploring the role of venture capital as a supporter of start-up companies.

The difference between this research and the previous one is the location of research conducted in Indonesia. It can be seen from the geographical location and differences in the culture in which the results of the research may differ from the previous studies conducted in Europe and America. This research is also interesting to do because Indonesia is a developing country and ranks first with the highest number of start-ups in the ASEAN regions. Until 2017, there had been 1559 start-ups in Indonesia (www.start- 
upranking.com). In addition, the fact that there have not been many researchers conducting similar research motivates the current researcher to conduct this research on the role of venture capital in start-up companies.

The results of the study contribute to the investment theory, namely providing knowledge in accounting science related to the capital or investment in the field of financial accounting or management accounting. It is expected the this research can give practical contribution to the start-up business people in finding out the criteria that are assessed and become a concern when the selection process is carried out by the venture capital before making an investment decision.

\section{Literature Review and Research Focus}

\section{Venture Capital}

Venture capital is an alternative non-bank funding aimed at and is expected to be able to support the growth of start-up companies. Keuschnigg (2004) revealed that venture capital has a role in creating new business models that are believed to make start-up companies grow faster and have added values, as well as more work and innovation results than those of the old business models. Burer and Wustenhagen (2008) revealed that venture capital has a role as a supporter of entrepreneurship and start-up companies. Venture capital serves as an important link to support business continuity.

Baum and Silverman (2004) stated that the task that must be carried out by venture capital companies is to identify and select potential start-up candidates and become trainers who can help start-up companies realize their potentials. The investments made by venture capital companies include businesses/fields in line with the investment portfolio and involve rational reasons before deciding on investment choices (Kaplan and Stromberg, 2001).

Venture capital is considered a high-risk financing institution because in doing financing, it does not require collateral or interest payments. Financing is done more easily than that required by the bank, so that venture capital is able to encourage the economy in Indonesia because capital problems can be assisted without having to apply for a loan from the bank (Maryani, 2015).

\section{The Financing Mechanism of Venture Capital}

The financing mechanism carried out by the venture capital is divided into two, single-tier approach and two-tier approach (Martono, 2002). The mechanism of single-tier approach is a venture capital approach to perform two functions, as a fund provider and fund manager. Fund providers can collect funds from individuals or companies as investors, and the funds raised will be invested in the company as the investment capital. The mechanism of single-tier approach is illustrated by Figure 1 . 


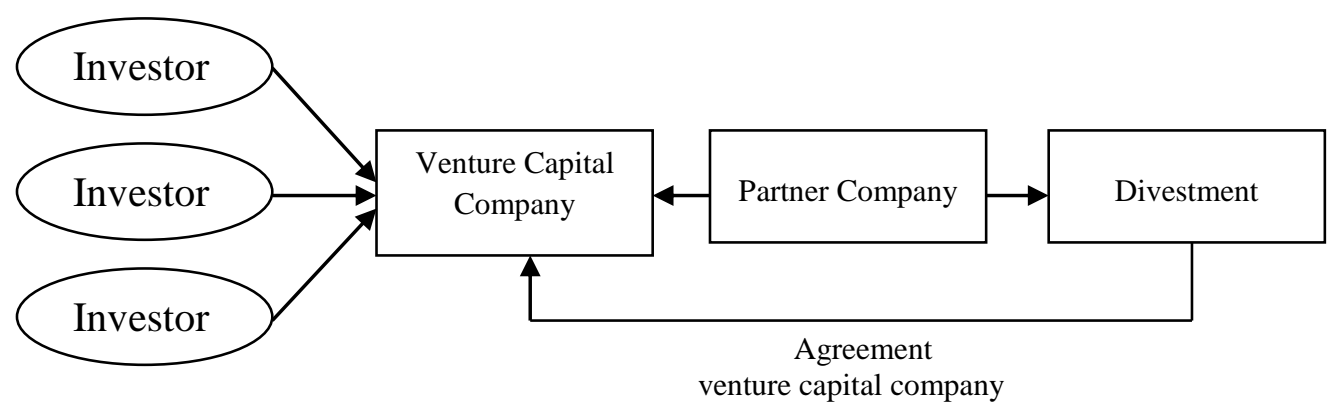

Figure 1 Funding Mechanism of single tier approach

Source: Martono (2002)

Martono (2002) describes the mechanisms of two-tier approach as an approach that involves two business entities separately. Both parties are the fund providers and fund managers. The fund provider collects from all its investors, either individuals or companies, while the fund manager has a special role in providing managerial assistance. The fund manager has a role in helping management manage the invested funds. The mechanism of twotier approach is illustrated by Figure 2 .

The practice of venture capital in Indonesia is likely to tend to lead to the one-tier approach mechanism. This is because the capital market as an unlimited funding provider is not involved in the venture capital in Indonesia. Utamaningsih (2014) stated that venture capital in Indonesia is a one-tier approach that is different from the two-tier approach. Two-tier approach involves venture capital and venture funds where venture funds are in the capital market, so they have an unlimited source of capital.

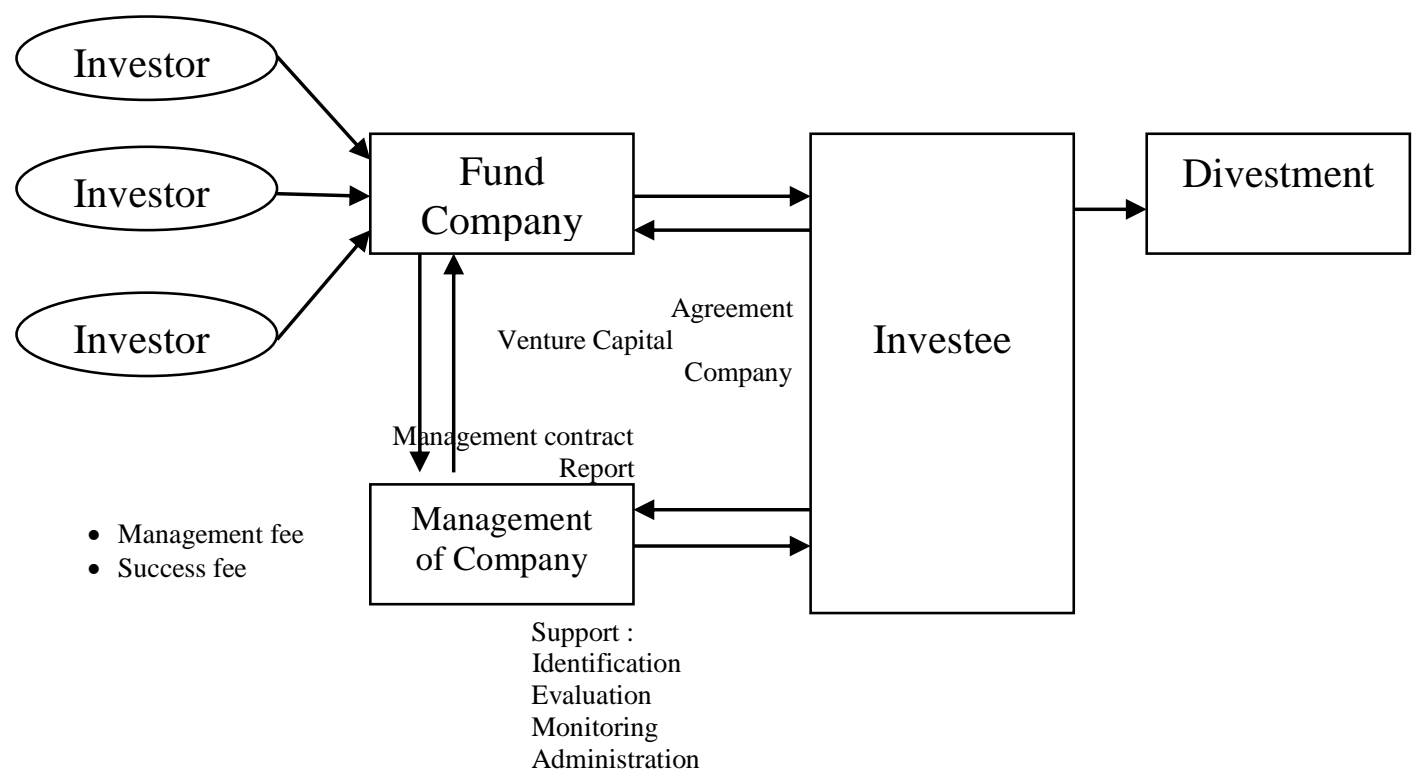

Figure 2 Funding Mechanism of two tier approach

Source: Martono (2002) 


\section{The Difference between Venture Capital and Banking}

Banks and other financial institutions have the $5 \mathrm{C}$ Principles before giving credit to their clients. (Maristiana, 2017) stated that credit is a productive asset that provides the main income in banking. The amount of credit that will be channelled usually will determine the profits obtained. Mistakes in channelling funds can be detrimental if they are not processed properly. Therefore, it is necessary to do 5Cs before the credit is given. The $5 \mathrm{C}$ referred to are Character, Capacity, Capital, Collateral, and Condition.

Maristiana (2017) also explained that each of the 5Cs, Character is the belief of the person who will be given credit to be truly trusted, usually reflected in the customer's background both work and personal data. Capacity is to see the customer's business ability in returning the credit received. Capital is seeing the use of capital by measuring in terms of liquidity, solvency, profitability, and other measures. Collateral is a guarantee given by the customer. Condition is the current condition by looking at the economic or political conditions in the present and in the future according to their respective sectors.

Collateral on banking is a guarantee given by prospective customers physically. The guarantee should usually be worth more than the amount of credit given. The validity of the guarantee must also be examined, so that if there is a problem, the guarantee is strong for bank guarantees of the credit given. Venture capital does not require analysis such as that conducted by banks so that collateral is not needed in funding provided by venture capital. Venture capital has its own deep analysis before investing in the start-up company and each venture capital has a different analysis depending on the investment sector and how much funding will be given.

\section{Venture Capital Divestment}

Venture capital in running its business has a risk of experiencing the divestment process. Divestment is the last stage that is carried out from venture capital financing, where venture capital can withdraw its equity participation in start-up companies (Uzzaman, 2016). In the case of divestment, the most important thing to do is to determine the share price of the venture capital (Kiwe, 2018). Pricing by venture capital usually depends on the valuation (value) of the start-up company.

The divestment can be carried out by choosing one of the various alternatives commonly used in the divestment mechanism. The ability to use this method will affect the financial performance of venture capital. Rahman (2003) stated that the choice of divestment in venture capital can be done by:

Initial Public Offering (IPO)

Divestment can be done by making a public offering through the capital market or IPO (Initial Public Offering). The IPO is a condition where for the first time the company's start-up shares can be traded on the stock exchange. By selling shares made to the public, venture capital can get cash 
or fresh funds where the funds received are the capital returns that are included by venture capital at start-up companies

Buy Back

Buy back is a repurchase of part or all of the shares by a start-up company from venture capital so that they become the private property again. The buy-back agreement for the inclusion of the venture capital share can be done in a Put or Call manner. Put is the right granted to the venture capital to ask start-up companies to buy back the share of shares owned by it at a price according to the venture capital financing agreement. Call is the right granted to the start-up company to buy back the share of venture capital shares in the same way as that of Put.

Exit

There are three definitions of exit at a start-up company. The first is when a start-up company that is given an investment has achieved an Initial Public Offering or M \& A (Merge \& Acquisition) with another company. The second exit is if the initiated company fails or closes (bankrupt) for various reasons. The third exit is when the venture capital or investors stop investing in startup companies.

Liquidation

Venture capital can divest by company liquidation. Liquidating a start-up company can be used as an alternative divestment if it cannot develop as expected or can be called a zombie because in these conditions, the start-up company will be more easily liquidated by selling all of its assets rather than looking for potential investors.

\section{Start-up Company}

Start-up is the initiated company or the company that has not been operating for a long time. A start-up company is a human institution designed to create products or services amid extreme uncertainty (Ries, 2011). Start-up companies are designed to find a repeat and scalable business model (Gompers \& Lerner, 2001). The definition expressed can mean that the start-up is an initiated company that is designed to find the right business model for the company in order to survive amid extreme uncertainty.

Gaujard (2008) stated that a company should have some special characteristics or criteria to be categorized as a start-up company, including:

1) A company that has not been long established (usually the age of the company is less than 3 years)

2) It has few workers or employees, which is usually fewer than 20 people. Unlike corporate companies, start-up companies only have few employees due to effective work, and there is no waste of funds for employee payroll. In addition, the human resource has multitasking capabilities meaning that every worker can concurrently work on multiple tasks. 
3) Engaged in technology. The venture/business commonly related to start-up companies will relate to technology and application use.

4) Operated in websites. The start-up company can be ascertained to have a site as the identity of the company because the operations used are in that field. Although the services offered are in the form of real products or services using applications, it will still use the website.

5) Still in the development stage. The business model usually offered by a start-up company is the earliest stage of development in a business.

Start-up companies have two potential possibilities in running their business, namely the potential for success and failure. Gompers and Lerner (2001) stated that the reason for failed start-up companies is the business uncertainty and information asymmetry related to start-ups compared to incumbent companies. Fabian and Ndofor (2007) revealed that the personality and purpose of entrepreneurs in carrying out business activities affect the performance, as well as the economic climate in the company.

The start-up company in running its business has a round investment, which generally does not only last once because a good start-up company will receive a round investment over and over until it reaches the exit. Uzzaman (2016) mentioned the stages of funding that occur at start-up companies, namely:

1) Round Seed. An initial stage investment, the investment received by start-up companies is still at the stage of product and feedback validation on the model business.

2) Series A. Series A stage is usually the stage where the Alfa or Beta version of a start-up product is finished, and the start-up is ready to get a certain number of users.

3) Series B. In this phase, business growth usually has increased significantly (scale up) and has generated revenue but has not generated profit.

4) Final Round. Start-up companies in this phase will try to grow sustainably.

The fact that there is still little research on VC in Indonesia is the reason why this research is important to do, especially with the rapid development of the start-up companies in Indonesia. This research explored two research questions, namely:

$R Q_{1}$ : What criteria are used by the venture capital companies before investing in start-ups?

$R Q_{2}$ : how is the role of the venture capital as a supporter of the start-up companies in Indonesia?

\section{Research Method}

This research applied qualitative research to find out more about the role of venture capital as a driver of start-up business in Indonesia. The research approach used is a case study approach. Sekaran (2009) revealed that case studies are very thick with a picture of a situation in the social or field 
environment. Case studies are conducted on the grounds that they are research strategies that are suitable for several conditions. First, the research questions is regarding how or why. Second, the researcher has few opportunities to control the events that will be investigated. Third, the focus of the research lies on contemporary phenomena in the real life context (Yin, 2013).

The research location is located in the city of Jakarta on the grounds that it is considered as the centre of the country's economy, and there are many large venture capital companies that invest in start-ups. Data collection was conducted with observations and interviews. The documentation in this study is in the form of interview recordings, or sources of information from the company websites that can be used as a complement to data processing. Observation was carried out by observing the activities that occurred in the venture capital, which is that there is a co-working space and this is then known to be one of the roles of venture capital in terms of networking. The objective of observation is to strengthen data validity that the company has implemented the venture capital concept.

In this case, the researcher becomes a passive observer without participating in organizational activities. Interviews were conducted with the informants at the venture capital, which involved three venture capital companies and represented by five informants from the three venture capital companies. The interviews conducted with the informants were structured and unstructured interviews. The structured interviews were done by setting a list of questions posed to the informants while the unstructured interviews were carried out by not adhering to the interview guidelines and more flexible depending on the conditions in the field and the other person. The five informants were represented by the vice presidents, portfolio directors, business analysts, research assistant and analyst. The CyberAgent party was only represented by one informant, the vice president directly. The vice president of the venture capital is the top leader and the party that is considered as the one who knows and understands the most about the company. In addition, it is also related to the willingness of the informants. The name of the informant was disguised for privacy reasons from the relevant venture capital and replaced with codification. The list of informants in this study is presented in Table 1.

The researcher tested the credibility of the data using triangulation. Sugiyono (2017) stated that triangulation consists of three types, namely triangulation of sources, techniques and time. The triangulation used by the researcher is the triangulation of sources by using a number of informants for data collection. The data analysis techniques used are data reduction,

Table 1 List of Informants

\begin{tabular}{lllc}
\hline No & Code & \multicolumn{1}{c}{ Company } & Position \\
\hline 1 & Informant A & Cyber Agent Ventures & Vice President \\
2 & Informant B & MDI by Telkom Indonesia & Portfolio Director \\
3 & Informant C & MDI by Telkom Indonesia & Busines Analyst \\
4 & Informant D & Skystar Capital & Research Assistant \\
5 & Informant E & Skystar Capital & Analyst \\
\hline
\end{tabular}


data presentation, conclusion drawing (Sugiyono, 2017). Data reduction is done by making questions, then collecting data and reducing them. Data presentation is done with narrative text, tables and images. The conclusion is made by drawing conclusions from the formulation of the problem.

The researcher used instruments to answer research questions. In the research instrument, there are indicators as a reference for making a list of interview questions with the informants. The research instrument is based on the research model conducted by Bocken (2015). The indicators were used to answer research questions regarding the criteria for providing investment indicated by the indicators of recognition, business success and failure, and the investment in business. The instrument of this research is shown in Table 2.

\section{Result and Discussion}

Basically, the investment process carried out by venture capital has a possible process that differs between one venture capital and another. This happens because there are no specific rules established and implemented

Table 2 Research Instrument

\begin{tabular}{|c|c|c|c|}
\hline No & Scoring Aspects & Indicators & Description \\
\hline 1 & $\begin{array}{l}\text { Criteria for granting } \\
\text { investment }\end{array}$ & Recognition & $\begin{array}{ll}\text { - } & \text { Company Background } \\
\text { - } & \text { Company Vision and Mission } \\
\text { - } & \text { Company Organizational Structure } \\
\text { - } & \text { Investment and Strategies } \\
\text { - } & \text { Funding Characteristics }\end{array}$ \\
\hline 2 & & $\begin{array}{l}\text { Business Success and } \\
\text { Failure }\end{array}$ & $\begin{array}{ll}\text { - } & \text { Sample of Business Success and } \\
& \text { Failure } \\
\text { - } & \text { Reason for Business Success and } \\
& \text { Failure } \\
\text { - } & \text { Indicators of Business Success and } \\
& \text { Failure } \\
\text { - } & \text { Business Model Update }\end{array}$ \\
\hline 3 & & Business Investment & $\begin{array}{l}\text { - Stages of start-up company's selection } \\
\text { - } \quad \text { Criteria of start-up company's selection } \\
\text { - } \quad \text { Parties involved in the selection } \\
\text { process }\end{array}$ \\
\hline 4 & Role of Venture Capital & $\begin{array}{l}\text { Investor's Support } \\
\text { and Start-up } \\
\text { Company's Needs }\end{array}$ & $\begin{array}{l}\text { - Guidance in the stages of business } \\
\text { advancement } \\
\text { - The difference of the supports } \\
\text { between conventional and start-up } \\
\text { companies } \\
\text { - } \quad \text { Role of venture capital companies in } \\
\text { business }\end{array}$ \\
\hline 5 & & Future Expectation & $\begin{array}{ll}\text { - } & \text { Future business model outlook } \\
\text { - } & \text { Expectation on the government } \\
\text { - } & \text { Expectation on the entrepreneur } \\
\text { - } & \text { Expectation on the people }\end{array}$ \\
\hline
\end{tabular}


together in Indonesia. Broadly speaking, the stages carried out are the same, and it is possible to vary the names of each venture capital. In applying for funding at the venture capital, not all start-up companies will be accepted and get funding. Therefore, knowledge is needed on the criteria set by the venture capital, so that start-up entrepreneurs are on target in targeting the venture capital to help fund their business. The results of the interviews with the informants regarding the criteria used before investing in the start-up are shown in Table 3.

Table 3 Summary of the Investment Granting Criteria

\begin{tabular}{|c|c|c|c|}
\hline Criteria & Cyber Agent Ventures & MDI by Telkom & Skystar Capital \\
\hline $\begin{array}{l}\text { Seeing Team } \\
\text { members }\end{array}$ & $\begin{array}{l}\text { "The team is a crucial part } \\
\text { and we (the company) will } \\
\text { always see who are the } \\
\text { founder and CEO of the } \\
\text { start-up. The company } \\
\text { assumes that IP (Intellectual } \\
\text { Property) from a start-up is } \\
\text { the human beings in it. The } \\
\text { quality of the team will } \\
\text { determine the decision to } \\
\text { entrust investment in the } \\
\text { start-up or not." }\end{array}$ & $\begin{array}{l}\text { "The team is very important } \\
\text { and needed at a start-up } \\
\text { because the main asset } \\
\text { owned by a start-up at the } \\
\text { beginning of the } \\
\text { establishment is a team. } \\
\text { Hence, it is important to see } \\
\text { each team member during the } \\
\text { selection process." }\end{array}$ & $\begin{array}{l}\text { "Before pitching, the } \\
\text { company will see education } \\
\text { background, expertise until } \\
\text { the time of establishing } \\
\text { relationships among teams. } \\
\text { The company considers it } \\
\text { before investing as it is the } \\
\text { main criterion. Passing the } \\
\text { process means passing 50\% } \\
\text { of the selection process." }\end{array}$ \\
\hline The Product Offered & $\begin{array}{l}\text { "Analysing a start-up that } \\
\text { proposes a business plan } \\
\text { cannot be viewed through } \\
\text { ideas, but it should be noted } \\
\text { that the products produced } \\
\text { will be in accordance with } \\
\text { customer expectations. A } \\
\text { problem can be seen as a } \\
\text { simple thing but somehow it } \\
\text { must be solved, and the } \\
\text { solution must be found." }\end{array}$ & $\begin{array}{l}\text { "A good start-up is a start-up } \\
\text { that can provide the answer } \\
\text { to the problem that exists in } \\
\text { the community. The product } \\
\text { offered must have benefits for } \\
\text { the community." }\end{array}$ & $\begin{array}{l}\text { "No matter how } \\
\text { imaginative the product is } \\
\text { offered to the community, } \\
\text { if it does not have } \\
\text { usefulness, it will be in } \\
\text { vain. The product can be } \\
\text { said to be successful in the } \\
\text { market by seeing how } \\
\text { sticky people are using it." }\end{array}$ \\
\hline Marketing strategy & & $\begin{array}{l}\text { "Before launching a product } \\
\text { into the market, start-up } \\
\text { companies must conduct } \\
\text { market trials and research on } \\
\text { the customer, compare prices, } \\
\text { and find out competitors } \\
\text { which have similar or of-a- } \\
\text { kind products. This is done to } \\
\text { formulate the marketing } \\
\text { strategy that is carried out } \\
\text { when launching the product." }\end{array}$ & $\begin{array}{l}\text { "One of the marketing } \\
\text { strategies can be done in } \\
\text { collaboration with the } \\
\text { media to disseminate data, } \\
\text { make promo videos, } \\
\text { approach consumer to } \\
\text { consumer (C2C), utilize co- } \\
\text { working space or join the } \\
\text { existing communities." }\end{array}$ \\
\hline Exit Strategy & $\begin{array}{l}\text { "Exit is the last step of the } \\
\text { start-up cycle. It is better for } \\
\text { a start-up to think about the } \\
\text { exit steps when the new } \\
\text { company is established. It's } \\
\text { not easy to think about the } \\
\text { exit step, but that doesn't } \\
\text { mean it's impossible to do." }\end{array}$ & & $\begin{array}{l}\text { "The exit strategy is } \\
\text { important to be owned and } \\
\text { thought out by a start-up. } \\
\text { The expected exit is IPO or } \\
\text { Merge and Acquisition (M } \\
\text { \& A), but every business } \\
\text { does have two risks. If the } \\
\text { final exit result is } \\
\text { liquidation, then it must be } \\
\text { accepted and made a } \\
\text { lesson." }\end{array}$ \\
\hline
\end{tabular}




\section{Determining Criteria for Investment Granting}

Before making a funding decision on a start-up company, generally venture capital has the criteria set out in selecting which are considered important and seeing future potentials. These criteria include:

\section{1) Seeing Team members}

The informant mentioned that most of the analysis process was to look at each member of the team and how to develop strong resources. It can be revealed from each member expertise, educational background and experience in each member. Uzzaman (2016) stated that the team is the main aspect of a start-up, so from the point of view of venture capitalists, it is the most important element. In addition, the team is the only real asset owned by a new start-up company.

Informant A who acts as the vice president of a venture capital stated that in analysing start-ups, investors would spend most of their time analysing the team of the company. The quality of the team will determine the investor's decision to entrust their capital to the company or not as stated below:

"The team is a crucial part and we (the company) will always see who are the founder and CEO of the start-up. The company assumes that IP (Intellectual Property) from a start-up is the humans in it. The quality of the team will determine whether or not to invest in the start-up."

Informant $\mathrm{C}$ who acts as a business analyst expressed the same opinion as disclosed by informant $A$ that the team is the main thing to be considered when starting the analysis. This is said in the following sentence:

"The team is very important and needed at a start-up because the main asset owned by a start-up at the beginning of the establishment is a team. Hence, it is important to see each team member during the selection process."

When conducting the selection process, analysts from venture capital will usually see the CEO (Chief Executive Officer) at the start-up. CEO is the most important position in the start-up. CEO quality often determines the success of a company. Uzzaman (2016) stated that a strong CEO will create a team that contributes and believes in goals, and can form a healthy corporate culture. The same was conveyed by informant D from Skystar Capital where $50 \%$ of the things highlighted during the selection process are who is behind the start-up team, the education background and expertise of each team member, and the length of relationship built among the members. This is stated in the following sentence:

"Before pitching, the company will see education background, expertise until the time of establishing relationships among teams. The company will consider it before making an investment as this is the main criterion. Passing the process means passing 50\% of the selection process."

The venture capital usually observes the composition of the team from the organizational structure because no matter how large the company is, it is still important to be able to manage it. The goal is to prevent confusion in 
carrying out their duties and responsibilities and to keep the company healthy.

The results of the research on the importance of team members have in common with those of Bocken (2015) resulting in that investors will judge a start-up starting from every person in the team because investors will know that the organization of a company is closely related to the success that will be obtained later.

\section{2) The Product Offered}

Before releasing the product, the start-up company must be able to define the problem and find a solution. A good product means having the ability to solve certain problems. In an interview with the informants, the researcher repeatedly caught that what the start-up companies have to do is to find the solution to a problem. This is supported by Kiwe (2018) that venture capitalists generally ask whether the product to be produced is the solution of a problem and what is the solution they offer/provide. Both of these questions are the important points raised by venture capitalists. Therefore, no matter how imaginative a product is or how smart the solution is, if the problem or difficulty that will be solved from a product is unclear, then the value of the product will weaken.

Informant A in his statement stated that the problem could look very simple but it still had to be solved and the solution sought as told in the following sentence:

"Analysing a start-up that proposes a business plan cannot be viewed through ideas, but it should be noted that the products produced will be in accordance with customer expectations. A problem can be seen as a simple thing but somehow it must be solved, and the solution must be found."

The same thing was revealed by informant B who acts as a portfolio director at MDI Ventures that start-up companies must have a solutive product as the answer to the problems that exist in the community. In addition, what needs to be considered is how much is the public interest in using the product launched in daily life As stated in the statement that:

"A good start-up is a start-up that can provide the answer to the problem that exists in the community. The product offered must have benefits for the community."

Informant E, the analyst from Skystar Capital, added that by giving an example of financial services (financial technology or commonly called FinTech) for some people using these services is considered confusing but actually important. In Indonesia, according to him, there are still many people who do not use banking services, so the sector still has the potential to be improved. He said that the FinTech sector could still develop and create a new unicorn in the future. 


\section{3) Marketing strategy}

The criteria assessed by venture capital look not only at the team members and the products offered but also another thing observed by analysts, the marketing strategy used. Marketing strategy is a social and managerial process where individuals or organizations get what is needed and desired through the creation, the offer and exchange of valuable products (Kotler, 1991).

Marketing strategy can be defined as a program to determine organizational goals and implement its mission. Jaynor (2011) defines marketing strategies as a fundamental tool planned to achieve the company goals by developing sustainable competitive advantages through the market entered and marketing programs used to serve these target markets.

The informant said that before throwing the products into the market, startups must do several things. First, conduct a market trial that is used to find a gap that is different from the existing idea development after seeing the market response. Second, do research on customers. The goal is to get customers by seeing the target customers and how many products are needed. Third, compare/do research on prices, aiming to see the suitability of prices offered with the target market. Fourth, find out competitors to be able to compete in a healthy way.

One informant pointed out that the marketing strategy can be done in various ways, one of which is by collaborating with the media to disseminate the data, making promo videos, consumer to consumer approaches, utilizing co-working space or joining the existing communities. This is as stated in the following statement:

"One of the marketing strategies can be done in collaboration with the media to disseminate data, make promo videos, approach consumer to consumer (C2C), utilize co-working space or join the existing communities."

As time goes by, venture capitalists usually help in marketing strategies. This supports the statement from Moore and Wustenhangen (2004) that venture capitalists actually work even though they are 'invisible' as the coaches or partners of entrepreneurs who are establishing and developing their businesses. Hence, it is hoped that capitalist coaches can help improve the performance of the start-up company.

\section{4) Exit Strategy}

Exit is the last step of a start-up's life cycle. All actions taken by a CEO and his team during building a top start-up are the exit (Uzzaman, 2016). The exit strategy is considered important that it must be developed as early as possible, even better done since the beginning of a new start-up. Therefore, the venture capitalist will see the exit strategy used by a start-up at the beginning of selection before funding. Kasmir (2010) explained that there are two exit strategies that can be done, namely IPO and M \& A. The IPO is a condition where for the first time start-up shares are traded on the stock exchange while $\mathrm{M} \& \mathrm{~A}$ (Merge and Acquisition) is a combination of two start- 
ups or companies to become an operational entity, where one start-up is combined with another.

Informant E said that every business must have two possibilities, success and failure. Every business certainly hopes to get success, but if it fails, it should be accepted as a lesson. This was revealed in the sentence below:

"The exit strategy is important to be owned and thought out by a start-up. The expected exit is IPO or Merge and Acquisition, but every business does have two risks. If indeed the final exit result is liquidation, it must be accepted as a lesson."

Uzzaman (2016) stated that entrepreneurs in the United States often get the capital from the successful business exit which is then reused to invest in the new start-up companies. Some people may feel the refusal to transfer startups and products to other companies because emotionally the team members are still tied to the previous start-up. Efforts to maintain the growth of the company must still be done, but another important thing that must be owned by start-up entrepreneurs is the exit strategy.

\section{The Role of Venture Capital as a Start-up Company Supporter}

One of the supporting factors of a start-up company is the funding assistance provided by venture capital while capital investment is to help accelerate the start-up performance (Marcus, Malen \& Ellis, 2013). Venture capital is a high-risk financing because the financing made by venture capital is different from that carried out by banks and other financial institutions. Financing carried out by the banks is in the form of loans or credit while venture capital directly invests in the company it finances (Soemitro, 2009).

\section{1) Assisting Access to Start-up Company's Funding}

Capital is one of the obstacles for businesses to start and develop. Capital for start-ups is very important because the founders usually have business and technology ideas, but lack access to funding. Uzzaman (2016) stated that the investors who can help with the solution to the problem are needed. Venture capital is one of the investors who can help with it. Financial assistance provided by venture capital is not only in providing investment, but also in the start-up management that it finances (Chase, 2012).

Informant D from Skystar Capital stated that his company was present to support start-ups in terms of funding and other activities such as networking. This is evidenced by the statement below:

"As mandatory, the company is committed to investing in start-ups that involve the techangle in it. Thus, the main thing to be done by the company is to do funding at start-ups."

The role of venture capital in funding is the main thing to do. Funding needs are very important in the establishment of new businesses. In addition, the needs for market access, market information, technical and operational skills, production, and post-production handling are also very important (Haikal, 2012). 
Other informants from MDI also expressed their opinions in the same way as the Informant $D$ stating that the main purpose of the company was to aim for funding. It is as expressed in the following sentence:

"The purpose of MDI in the Indonesian market is to scale up the business.

One of the ways that can be done is by investing in start-ups."

The role of venture capital in providing financial assistance at start-ups has in common with the results of the research conducted by Bocken (2015) that is to do funding by considering appropriate strategies and seeing the market potential of a product. The funding assistance is expected to improve business sustainability and most importantly, investments are made in the transformation and innovative business.

New innovations in technology can be more easily realized if there is support from venture capital as what happen in various developed countries (Utamaningsih, 2014). For example, in China, venture capital successfully helped bring up and support the growth and development of new businesses based on innovation. Not only China, in the US, most of the development of companies based on innovation and technology are supported by venture capital.

\section{2) Assisting Newly Developed Start-up Companies}

Financing carried out by venture capital is the financing carried out at the small or newly established start-ups that save the potential to grow into the large ones. Venture capital is expected to play a role in helping new start-ups to grow while the investment capital play a role not only in the capital side but also in other aspect, that is encouraging convenience or providing facilities to run the start-up company's business.

Keushcnigg (2004) argued that venture capital has a role in creating new business models that are believed to make start-up develop faster and the value created or the products produced have added value. The theory put forward is in accordance with the conditions that occur at this time, in which the venture capital in Indonesia helps many new start-up companies develop in many ways and various things.

The same thing was expressed by Informant A, who thought that venture capital acted as a supporter in the development of the start-up cycle as stated below:

"The activities carried out by the company are not only in terms of investment, but also as the supporter of the start-ups. What the company wants to do is to help entrepreneurs go one step further and help future business start-up skills."

Uzzaman (2016) exemplifies one of the things that venture capital can do in helping newly developing start-ups, i.e. to cooperate. Cooperation is considered important for the growth of a start-up. The form of cooperation is, for example, start-up companies with established companies. In addition to expanding business networks, it is beneficial for both parties. 
Informant B, the portfolio director from MDI Ventures, gave an example. If one of the start-ups that is funded ran a business in telecommunications, it can do internal cooperation with Telkom Indonesia in terms of the automatic SMS (Short Message Service) sending feature to the customer service which is considered mutually beneficial. Though it is not easy for a start-up to make direct contact with a large company, if there is a connection or an extensive network, it is not impossible that the venture capital can help the start-up enter the link it has.

\section{3) Supporting Networking and Mentoring Activities}

The role of venture capital does not stop at funding assistance and helping new start-ups grow, but it has a role in supporting networking and mentoring activities. Uzzaman (2016) stated that networking activities can be done by building a co-working space, providing business incubators, and becoming an accelerator at the start-up. Mentoring activities can be carried out and collaborate with the universities, practitioners, and large companies that can work together to build a conducive ecosystem to the economic development in Indonesia.

Informant A from CyberAgent revealed that his company provided coworking space to assist start-up activities while in mentoring it will help facilitate training with the practitioners and other professionals. This was revealed in the statement below:

"CyberAgent has a co-working space to support start-up activities. Its function is to facilitate start-ups to run better by providing workspace so that it is possible for these entrepreneurs to find investors for their businesses. Then, mentoring is the function of the company as a start-up supporter where they have limitation such as how to educate the market and treat customers. Such information will involve other parties."

Not all founders have networks to mentors who are influential and have big names to support the business that will be developed. It is expected that venture capital can bridge and play a role to link this.

In line with Informant A, Informant $E$ also conveyed the same thing. In terms of networking, he will try to help start-ups become more scalable and enter a venture capital network or link.

The role of venture capital in terms of mentoring and networking supports the theory proposed by Burer and Wustenhangen (2008) that venture capital has a role as a maintainer or supporter of entrepreneurs and start-up companies. One of the ways is to monitor and assist in networking activities.

\section{4) Scaling Up the Market Access of the start-up Products}

The start-up companies that find products or are considered able to answer the problems that exist in the community may not be able to produce and successfully market the results of their products. The production and marketing of products require skills, experience, and marketing network that can guarantee the smooth running of the business. It is expected that with 
Table 4 Summary of Venture Capital Role

\begin{tabular}{|c|c|c|c|}
\hline $\begin{array}{c}\text { Roles of } \\
\text { Venture Capital }\end{array}$ & $\begin{array}{l}\text { CyberAgent } \\
\text { Ventures }\end{array}$ & $\begin{array}{c}\text { MDI } \\
\text { by Telkom }\end{array}$ & $\begin{array}{l}\text { Skystar } \\
\text { Capital } \\
\end{array}$ \\
\hline Funding Access & $\begin{array}{l}\text { "The company's vision is to } \\
\text { help entrepreneurs in } \\
\text { Indonesia, and investment } \\
\text { is the end goal of the } \\
\text { company." }\end{array}$ & $\begin{array}{l}\text { "The purpose of MDI in } \\
\text { the Indonesian market is } \\
\text { to scale up the business. } \\
\text { One of the ways that can } \\
\text { be done is by investing in } \\
\text { start-ups." }\end{array}$ & $\begin{array}{l}\text { "As mandatory, the } \\
\text { company is committed to } \\
\text { investing in start-ups that } \\
\text { involve the techangle in } \\
\text { it. Thus, the main thing } \\
\text { to be done by the } \\
\text { company is to do funding } \\
\text { at start-ups." }\end{array}$ \\
\hline $\begin{array}{l}\text { Assisting New } \\
\text { Developing start-ups }\end{array}$ & $\begin{array}{l}\text { "The activities carried out } \\
\text { by the company are not } \\
\text { only in terms of } \\
\text { investment, but also as the } \\
\text { supporter of the start-ups. } \\
\text { What the company wants } \\
\text { to do is to help } \\
\text { entrepreneurs go one step } \\
\text { further and help future } \\
\text { business start-up skills." }\end{array}$ & $\begin{array}{l}\text { "Many things can be done } \\
\text { by companies to help } \\
\text { start-ups expand their } \\
\text { networks. One way is to } \\
\text { collaborate. The } \\
\text { collaboration can be done } \\
\text { between Telkom and the } \\
\text { outside parties as long as it } \\
\text { is beneficial for both of } \\
\text { them." }\end{array}$ & $\begin{array}{l}\text { "The role of the company } \\
\text { does not stop at funding, } \\
\text { but helps new start-ups } \\
\text { to develop like improving } \\
\text { the ideas and adding } \\
\text { innovations to the } \\
\text { products and so on." }\end{array}$ \\
\hline $\begin{array}{l}\text { Networking and } \\
\text { Mentoring Activities }\end{array}$ & $\begin{array}{l}\text { "CyberAgent has a co- } \\
\text { working space to support } \\
\text { start-up activities. Its } \\
\text { function is to facilitate } \\
\text { start-ups to run better by } \\
\text { providing workspace so } \\
\text { that it is possible for these } \\
\text { entrepreneurs to find } \\
\text { investors for their } \\
\text { businesses. Then, } \\
\text { mentoring is the function } \\
\text { of the company as a start- } \\
\text { up supporter where they } \\
\text { have limitation such as } \\
\text { how to educate the market } \\
\text { and treat customers. Such } \\
\text { information will involve } \\
\text { other parties." }\end{array}$ & $\begin{array}{l}\text { "One of the efforts made } \\
\text { by the company to help } \\
\text { start-ups is to bring start- } \\
\text { ups into the company } \\
\text { circle or help them with } \\
\text { networking as start-ups } \\
\text { will commonly ask for } \\
\text { advice or assistance to the } \\
\text { company, so the company } \\
\text { must intervene to help." }\end{array}$ & $\begin{array}{l}\text { "In terms of networking, } \\
\text { the company will try to } \\
\text { make start-ups more } \\
\text { scalable by putting them } \\
\text { into the corporate } \\
\text { network to fulfil their } \\
\text { needs." }\end{array}$ \\
\hline $\begin{array}{l}\text { Scaling Up the } \\
\text { Market Access of the } \\
\text { Start-up Products }\end{array}$ & & $\begin{array}{l}\text { "There are several } \\
\text { strategies that can be done } \\
\text { to expand the access to } \\
\text { start-up products by doing } \\
\text { market analysis and a } \\
\text { product strategy plan, } \\
\text { paying attention to prices } \\
\text { and packaging, paying } \\
\text { attention to the product } \\
\text { positioning consistently, } \\
\text { designing marketing plans, } \\
\text { executing the strategies } \\
\text { that have been made, and } \\
\text { monitoring when the } \\
\text { product has been launched } \\
\text { in the community." }\end{array}$ & \\
\hline
\end{tabular}


the entry of venture capital that has management capabilities and a strong business background as a business partner, the success of start-ups will be bigger. In expanding the market access for the start-up products, several strategies are needed.

It was mentioned by Informant B that there were several strategies that could be done to expand the market access of the products. The strategy is expressed in sentence below:

"There are several strategies that can be done to expand the access to start-up products by doing market analysis and a product strategy plan, paying attention to prices and packaging, paying attention to the product positioning consistently, designing marketing plans, executing the strategies that have been made, and monitoring when the product has been launched in the community."

It is expected that a good and well-planned strategy will be able to reduce the risk of failure and help start-ups to achieve their goals. The summary of venture capital role is as a support for start-up companies shown in Table 4.

\section{Conclusion}

This research aimed to explore the criteria used by the venture capital before investing in start-up companies, as well as its role to become a startup supporter in Indonesia. The results show that the criteria used by the venture capital before making the investment process is to see the team members, the products that will be offered, marketing and exit strategies. These criteria are needed with the aim of discovering the potential of business and products in the future. The roles of the venture capital as a supporter of the start-up companies in Indonesia are, among others, helping access to start-up funding, helping new start-ups, supporting networking and mentoring activities, and helping to expand access to start-up product markets.

The limitation of this study lies in the research informants because of the difficulty of finding venture capital that is willing to be questioned and to be the informant. Second, the information from the venture capital is closed because not all informants are willing to inform their start-up portfolio that is funded. Therefore, the researcher cannot confirm and conduct in-depth research on start-ups that have received the investment from the venture capital.

For further research, it is suggested to add additional informants that involve start-up companies that get the investments from the venture capital so that the role of the venture capital can be confirmed. In addition, research can be conducted with a survey to test statistically the contribution of the venture capital with more research samples than the approach carried out using case studies. 


\section{References}

Baum, J.A.C., \& Silverman, B.,S. (2004). Picking winners or building them? Alliance, intellectual, and human capital as selection criteria in venture financing and performance of biotechnology startups. Journal Bussiness Ventura, 19(3), 411-436. https://doi.org/10.1016/j.jbusvent.2014.12.001

Bocken, N.M.P.(2015). Sustainable venture capital-catalyst for sustainable start up success?. Journal of Cleaner Production, 108. 647-658. https://doi.org/10.1016/i.jclepro.2015.05.079

Buchner, A., Abdulkadir, M., \& Armin.,S. (2017). Diversification, risk and return in venture capital. Journal of Business Venturing, 31, 519-535. https://doi.org/10.1016/j.jbusvent.2017.05.005

Bürer, M.J., \& Wüstenhagen, R. (2008). Cleantech venture investors and energy policy risk: an exploratory analysis of regulatory risk management strategies. In: Wüstenhagen, R., Hamschmidt, J., Sharma, S., Starik, M. (Eds.), Sustainable Innovation and Entrepreneurship. Edward Elgar Publishing, 290309.

Chase, R. (2012). How Technology Enables the Shared Economy. Available at: http://www.Greenbiz.com/video/2012/05/02/how-technologyenables-shared-economy

Fabian, F.H., \& Ndofor, H. (2007). In : Lumpkin, T., Katz, J. (Ed), The context of enterpreneurial processes : one size doesn't fit all. Advance Enterpreeneurship, 10, 249-280. https://doi.org/10.1016/s10747540(07)10010-6

Gaujard, C. (2008). An innovative organization in a context of ruptures: a french ict start-up ideal type.Journal of Innovation Economic, 45(1). https://doi.org/10.3917/jie.002.0105

Gompers, P., \& Lerner, J. (2001). The venture capital revolution. Journal Economic Perspective, 15(2), 145-168. https://doi.org/10.1257/jep.15.2.145

Haikal, S. (2012). Modal Ventura di Indonesia Bukan Lembaga Kenangan, Proceeding Seminar Nasional : Kesiapan Industri Perbankan dan Bisnis dalam Menghadapi Asean Economic Community 2015. Universitas Stikubank Semarang, 7 Juni 2012

Kaplan, S., \& Stromberg, P. (2001). Venture capitalists as principals: contracting, screening, and monitoring. American Economics Review, 91(2), 426-430. https://doi.org/10.3386/w8202

Kasmir. (2010). Bank dan Lembaga Kenangan Lainnya. Jakarta : RajaGrafindo Persada, 2001

Kasali. R.(2017). Disruption. Jakarta : Gramedia Pustaka Utama.

Keuschnigg, C. (2004). Venture capital backed growth. Joumal Economic Growth. 9(2), 239-261. https:// doi.org/10.1023/b:joeg.0000031428.35711.fc

Kiwe, L. (2018). Jatub Bangun Bos-Bos Startup. Yogyakarta : Checklist

Kotler, P. (1991). Manajemen Pemasaran Analisis, Perencanaan Implementasi dan Pengendalian. Jakarta : Universitas Indonesia

Lee, H.S. (2017). Peer network in venture capital. Journal of Empirical Finance. 41, 19-30. https://doi.org/10.1016/j.jempfin.2016.12.006

Marcus, A., Malen, J., \& Ellis, S. (2013). The promise and pitfalls of venture capital as an asset class for clean energy investment: research questions for organization and natural environment scholars. Journal Organization Environment. 26(1), 31-60. https://doi.org/10.1177/1086026612474956

Maristiana, S. (2017). Pengaruh analisis 5C (Character, Capacity, Capital, Collateral, and Condition) dalam Pemberian Kredit: di BRI Unit Indraprasta. Thesis. Universitas Pandanaran Semarang, Indonesia

Martono. (2002). Bank dan Lembaga Keuangan Lain. Yogyakarta : Ekonisia. Maryani, D. (2015). Peran Perusabaan Modal Ventura Dalam Mengembangkan UMKM (Studi pada PT PNM Ventura Syariah). Thesis. Universitas Islam Negeri Syarif Hidayatullah, Indonesia. 
Moore, B., \& Wustenhagen, R. (2004). Innovative and sustainable energy technologies : the role of venture capital. Business Strategic Environment, 13(4), 235-245. https://doi.org/10.1002/bse.413

Ramdhan, H.,E. (2016). Startup Business Model : 50 Model Bisnis dari 100++ Startup Lokal dan Mancanegara. Jakarta : Penebar Plus

Rahman, H. (2003). Segi-Segi Hukum dan Manajemen Modal Ventura Serta Pemikiran Alternatif Ke Arah Modal Ventura Yang Sesuai Dengan Kultur Bisnis Di Indonesia. Bandung : PT Citra Aditya Bakti

Raynor, M.E.(2011). Disruption theory as a predictor of innovation success/failure. Journal Strategy and Leadership, 39(4), 27-30. https://doi.org/10.1108/10878571111147378

Ries, E. (2011). The Learn Startup. New York : Crown Business

Soemitra, Andri. 2009. Bank dan Lembaga Keuangan Syariah. Jakarta : Kencana Prenada Media Group

Sekaran, U. (2009). Research Methods for Business-Metodologi Penelitian untuk Bisnis. (Edisi 4). Jakarta : Salemba Empat

Sugiyono. (2017). Metode Penelitian Kualitatif. Bandung : Alfabeta

Tecker, D., Teker, S., \& Teraman, O. (2016). Venture capital Markets : A Cross Country Analysis. Istanbul Conference of Economic and Finance. ICEF 2015, 22-23 October 2015. Istanbul-Turkey. https://doi.org/10.1016/s2212-5671(16)30192-7

Utamaningsih, A. (2014). Modal Ventura : Perubahan Paradigma Pendanaan Di Indonesia dan Agenda Riset di Masa Depan. Jurnal Polibisnis, 6(2)

Utami, S.,S. (2007). Pengaruh Kepemimpinan dalam Perubahan Organisasi. Jurnal Ekonomi dan Kewirausahaan, 7(2), 124-129

Uzzaman, A. (2016).Startuppedia : Panduan Membangun Startup Ala Silicon Valley. (Cetakan ke-5). Yogyakarta : Bentang Pustaka

Yin, R.,K. (2013). Case Study : Design And Methods. Mudzakir, M.D. (Penerjemah). Studi Kasus Desain \& Metodologi. Depok : PT Rajagrafindo Persada 